\title{
Communication
}

\section{Antioxidant Activities of Hot Water Extracts from Various Spices}

\author{
Il-Suk Kim ${ }^{1}$, Mi-Ra Yang ${ }^{1}$, Ok-Hwan Lee ${ }^{2, *}$ and Suk-Nam Kang ${ }^{1, *}$ \\ 1 Department of Animal Resources Technology, Gyeongnam National University of Science and \\ Technology, Gyeongnam, 660-758, Korea; E-Mails: iskim@gntech.ac.kr (I.-S.K.); \\ karisto2000@ nate.com (M.-R.Y.) \\ 2 Department of Food Science and Biotechnology, Kangwon National University, Chuncheon, \\ 200-701, Korea
}

* Authors to whom co-correspondence should be addressed; E-Mails: loh99@kangwon.ac.kr (O.-H.L.); whitenightt@hanmail.net (S.-N.K.); Tel.: +82-33-250-6454 (O.-H.L.); +82- 55-751-3512 (S.-N.K.); Fax: +82-33-241-0508 (O.-H.L.); +82-55-751-3689 (S.-N.K.).

Received: 25 April 2011; in revised form: 7 June 2011 / Accepted: 15 June 2011 /

Published: 21 June 2011

\begin{abstract}
Recently, the natural spices and herbs such as rosemary, oregano, and caraway have been used for the processing of meat products. This study investigates the antioxidant activity of 13 spices commonly used in meat processing plants. The hot water extracts were then used for evaluation of total phenolic content, total flavonoids content and antioxidant activities. Our results show that the hot water extract of oregano gave the highest extraction yield $(41.33 \%)$ whereas mace $(7.64 \%)$ gave the lowest. The DPPH radical scavenging ability of the spice extracts can be ranked against ascorbic acid in the order ascorbic acid $>$ clove $>$ thyme $>$ rosemary $>$ savory $>$ oregano. The values for superoxide anion radical scavenging activities were in the order of marjoram $>$ rosemary $>$ oregano $>$ cumin $>$ savory $>$ basil $>$ thyme $>$ fennel $>$ coriander $>$ ascorbic acid. When compared to ascorbic acid $(48.72 \%)$, the hydroxyl radical scavenging activities of turmeric and mace were found to be higher $(\mathrm{p}<0.001)$. Clove had the highest total phenolic content $(108.28 \mu \mathrm{g}$ catechin equivalent $(\mathrm{CE}) / \mathrm{g})$. The total flavonoid content of the spices varied from $324.08 \mu \mathrm{g}$ quercetin equivalent $(\mathrm{QE}) / \mathrm{g}$ for thyme to $3.38 \mu \mathrm{g} \mathrm{QE} / \mathrm{g}$ for coriander. Our results indicate that hot water extract of several spices had a high antioxidant activity which is partly due to the phenolic and flavonoid compounds. This provides basic data, having implications for further development of processed food products.
\end{abstract}


Keywords: spices; antioxidant activity; radical scavenging activity; total phenolic content; total flavonoid content

\section{Introduction}

Oxidation is one of the major causes of chemical spoilage, resulting in rancidity and/or deterioration of the nutritional quality, color, flavor, texture and safety of foods [1,2]. It is well known that reactive oxygen species (ROS) formed in vivo, such as superoxide anion, hydroxyl radical and hydrogen peroxide, are highly reactive and potentially damaging transient chemical species. The oxidative damages caused by ROS on lipids, proteins and nucleic acids may trigger various chronic diseases, such as coronary heart disease, atherosclerosis, cancer and aging [3,4]. Antioxidant refers to a compound that can delay or inhibit the oxidation of lipids or other molecules by inhibiting the initiation or propagation of oxidative chain reactions and can thus prevent or repair the damage done to the body's cells by oxygen [5].

Plants, including herbs and spices, have many phytochemicals which are a potential source of natural antioxidant, e.g., phenolic diterpenes, flavonoids, alkaloids, tannins and phenolic acids [6-8]. Natural antioxidants are known to protect cells from damage induced by oxidative stress, which is generally considered to be a cause of aging, degenerative diseases, and cancer [9]. These health promoting effects of antioxidants from plants and spices are thought to arise from their protective effects by counteracting ROS. Spices, like turmeric, fenugreek, mustard, ginger, etc. may offer many health benefits and have been proven to counteract oxidative stress in vitro and in vivo [10,11]. Most of these spices have been intensely studied only for their active components like phenolic acids and flavonoids $[12,13]$.

Although the efficacy and mechanisms of action of spices have not been tested scientifically in most cases, these simple medicinal preparations often mediate beneficial responses due to their active chemical constituents [14]. Therefore, the objective of this study was to determine the total phenolic and total flavanoid contents and antioxidant properties of spices used in meat processing plants and to investigate the relationship between phenolic content and antioxidant activity.

\section{Results and Discussion}

\subsection{Extract Yields, Total Phenolic Contents, and Total Flavonoid Contents}

Table 1 lists the 13 spices used in this study, as well as their extraction yields, and total phenolic and total flavonoids contents. The differences between the extracts for these parameters were statistically significant $(\mathrm{p}<0.001)$. The extraction yields of hot water extracts obtained for the 13 species ranged from $41.33 \%$ to $7.64 \%$. The extraction yield can be ranked as oregano $>$ thyme > basil > rosemary, clove, marjoram and savory > coriander > fennel, turmeric and caraway > cumin > mace. These results are in good agreement with the study by Hinneburg et al. [15], in which water extraction yields of several spices were ranged from $88 \mathrm{mg} / \mathrm{g}(8.8 \%)$ to $422 \mathrm{mg} / \mathrm{g}(42.2 \%)$. 
The crude hot water extracts of the present study were used for comparison of their antioxidant activities, i.e., DPPH radical scavenging activity, hydroxyl radical scavenging activity, and superoxide anion radical scavenging activity. The total phenolic and total flavonoids contents were also determined for the hot water extracts, using colorimetric methods.

Phenolic substances have been shown to be responsible for the antioxidant activity of plant materials [16]. The total amount of phenolic and flavonoids present in the water extracts of the selected spices are shown in Table 1. Clove had the highest total phenolic content (108.28 $\mu \mathrm{g} \mathrm{CE} / \mathrm{g})$, while mace had the lowest value $(6.50 \mu \mathrm{g} \mathrm{CE} / \mathrm{g})$, using the standard curve of catechin $\left(\mathrm{R}^{2}=0.9482\right)$. The total phenolic content in decreasing order was clove $>$ thyme $>$ savory $>$ rosemary $>$ oregano, basil and marjoram > caraway, cumin, fennel, coriander, turmeric and mace $(\mathrm{p}<0.001)$.

Table 1. Extraction yield (\%), total phenolic content, and total flavonoids content of how water extract of various spices.

\begin{tabular}{ccccc}
\hline $\begin{array}{c}\text { Common } \\
\text { name }\end{array}$ & Botanical Name & $\begin{array}{c}\text { Extraction } \\
\text { yield } \\
(\boldsymbol{\%})\end{array}$ & $\begin{array}{c}\text { Total phenolic } \\
\text { content } \\
(\boldsymbol{\mu g ~ C E} / \mathbf{g})\end{array}$ & $\begin{array}{c}\text { Total flavonoid } \\
\text { content } \\
(\boldsymbol{\mu g} \mathbf{Q E} / \mathbf{g})\end{array}$ \\
\hline Rosemary & $\begin{array}{c}\text { Rosmarinus } \\
\text { officinalis }\end{array}$ & $19.75 \pm 0.43^{\mathrm{d}}$ & $42.58 \pm 1.01^{\mathrm{d}}$ & $269.84 \pm 6.50^{\mathrm{b}}$ \\
Oregano & Origanum vulgare & $41.33 \pm 5.13^{\mathrm{a}}$ & $23.36 \pm 0.93^{\mathrm{e}}$ & $156.93 \pm 9.36^{\mathrm{c}}$ \\
Caraway & Carum carvi & $12.00 \pm 0.72^{\mathrm{ef}}$ & $9.92 \pm 0.11^{\mathrm{f}}$ & $45.01 \pm 2.27^{\mathrm{g}}$ \\
Clove & Syzygium aromaticum & $19.58 \pm 0.14^{\mathrm{d}}$ & $108.28 \pm 7.11^{\mathrm{a}}$ & $75.97 \pm 0.01^{\mathrm{f}}$ \\
Turmeric & Curcuma longa & $12.50 \pm 0.66^{\mathrm{ef}}$ & $58.28 \pm 3.55^{\mathrm{b}}$ & $324.08 \pm 4.34^{\mathrm{a}}$ \\
Thyme & Thymus vulgaris & $32.03 \pm 0.78^{\mathrm{b}}$ & $7.78 \pm 0.31^{\mathrm{f}}$ & $14.25 \pm 0.54^{\mathrm{h}}$ \\
Basil & Ocimum basilicum & $24.59 \pm 0.19^{\mathrm{c}}$ & $20.25 \pm 0.85^{\mathrm{e}}$ & $131.60 \pm 17.83^{\mathrm{d}}$ \\
Marjoram & Maiorana hortensi & $18.07 \pm 0.70^{\mathrm{d}}$ & $20.44 \pm 0.62^{\mathrm{e}}$ & $157.73 \pm 7.06^{\mathrm{c}}$ \\
Mace & Myristica fragrans & $7.64 \pm 0.71^{\mathrm{g}}$ & $6.50 \pm 0.32^{\mathrm{f}}$ & $7.67 \pm 0.83^{\mathrm{h}}$ \\
Fennel & Foeniculum vulgare & $11.38 \pm 0.61^{\mathrm{ef}}$ & $9.36 \pm 0.21^{\mathrm{f}}$ & $44.76 \pm 2.32^{\mathrm{g}}$ \\
Coriander & Coriandrum sativum & $13.73 \pm 1.01^{\mathrm{e}}$ & $9.22 \pm 0.09^{\mathrm{f}}$ & $3.38 \pm 0.09^{\mathrm{h}}$ \\
Savory & Satureja & $17.67 \pm 1.04^{\mathrm{d}}$ & $48.07 \pm 1.61^{\mathrm{c}}$ & $35.19 \pm 5.84^{\mathrm{g}}$ \\
Cumin & Cuminum cyminum & $10.27 \pm 0.79^{\mathrm{fg}}$ & $10.17 \pm 0.68^{\mathrm{f}}$ & $101.34 \pm 4.08^{\mathrm{e}}$ \\
\hline
\end{tabular}

Note: The spices samples were refluxed with hot water at a temperature from 80 to $100{ }^{\circ} \mathrm{C}$ for $3 \mathrm{~h}$, and the extraction was repeated two times. Total phenolic content expressed as milligrams of catechin equivalent (CE)/g of extract; Total flavonoid content expressed as milligrams of quercetin quivalent $(\mathrm{QE}) / \mathrm{g}$ of extract; The extraction yield (\%) was calculated as (g of extract/g of dried spices $) \times 100 .{ }^{\mathrm{a}-\mathrm{h}}$ Values are means \pm S.D. significant difference between the samples $(\mathrm{n}=6)$ $(\mathrm{p}<0.05)$.

Flavonoid as one of the most diverse and widespread group of natural compounds are probably the most important natural phenolics. These compounds possess a broad spectrum of chemical and biological activities including radical scavenging properties [16,17]. Using the standard curve of quercetin $\left(\mathrm{R}^{2}=0.9825\right)$, the total flavonoid content of spices varied from $324.08 \mu \mathrm{g} \mathrm{QE} / \mathrm{g}$ for thyme to $3.38 \mu \mathrm{g} \mathrm{QE} / \mathrm{g}$ for coriander. The total flavonoid content in decreasing order was 
thyme $>$ rosemary $>$ marjoram and oregano $>$ basil $>$ cumin $>$ clove $>$ caraway and fennel $>$ savory $>$ turmeric, mace and coriander $(\mathrm{p}<0.001)$. It is known that the higher the phenolic and flavonoid contents of spices, the higher its antioxidant activities. Rice-Evans et al. [18] reported that the antioxidant properties of phenolic acids and flavonoids are due to their redox properties, ability to chelate metals and quenching of singlet oxygen.

\subsection{DPPH Radical Scavenging Activity}

2,2-Diphenyl-1-picrylhydrazyl (DPPH) is widely used to test the ability of compounds to act as free radical scavengers or hydrogen donors, and to evaluate antioxidant activity of foods [1]. Figure 1 shows that the DPPH radical scavenging ability of the extracts can be ranked in the order clove $(84.22 \%)>$ thyme $(70.79 \%)>$ rosemary $(56.98 \%)>$ savory $(53.51 \%)>$ oregano $(45.43 \%)>$ basil $(39.63 \%)>$ cumin $(35.02 \%)>$ caraway $(30.67 \%)$, coriander $(30.40 \%)$, marjoram $(30.22 \%)>$ tumeric $(24.43 \%)>$ mace $(20.94 \%)>$ fennel $(10.48 \%)$. The observed differential scavenging activities of the extracts against the DPPH system could be due to the presence of different compounds in the extract. Although the DPPH radical scavenging activities of the spices were less $(p<0.05)$ than those of ascorbic acid, the study revealed that most spices had free radical scavengers or inhibitors, acting possibly as primary antioxidants. In addition, a significant and linear relationship existed between the DPPH scavenging activity and phenolic content (Table 2), indicating that phenolic compounds are major contributors to antioxidant activity. The highly significant correlations obtained in this study support the hypothesis that phenolic compounds contribute significantly to the DPPH radical scavenging capacity of spice plants $(r=0.9158, \mathrm{p}<0.001)$. The good correlation between the results from total phenolics analysis and the antioxidative assays has been previously reported [19]. Moreover, Liu et al. [20] have reported the clove extract was significantly higher in the total phenol content and DPPH radical scavenging activity than other Chinese herbal plant. Although it is possible that the DPPH radical scavenging activity of spices could be mediated by individual phenolic acids, the overall antioxidant potential of spices are likely exhibited by the synergistic effect of the combinations of total phenolic acids and other antioxidant components including antioxidant vitamins considering the wide mixture of phenolic antioxidants present in spices extract. 
Figure 1. DPPH radical scavenging activities of hot water extracts of spices at a concentration of $1 \mathrm{mg} / \mathrm{mL}$ ( $\mathrm{n}=6$, error bars represent standard deviation). ${ }^{\mathrm{a}-1}$ Values are significantly different between the samples $(\mathrm{p}<0.001)$.

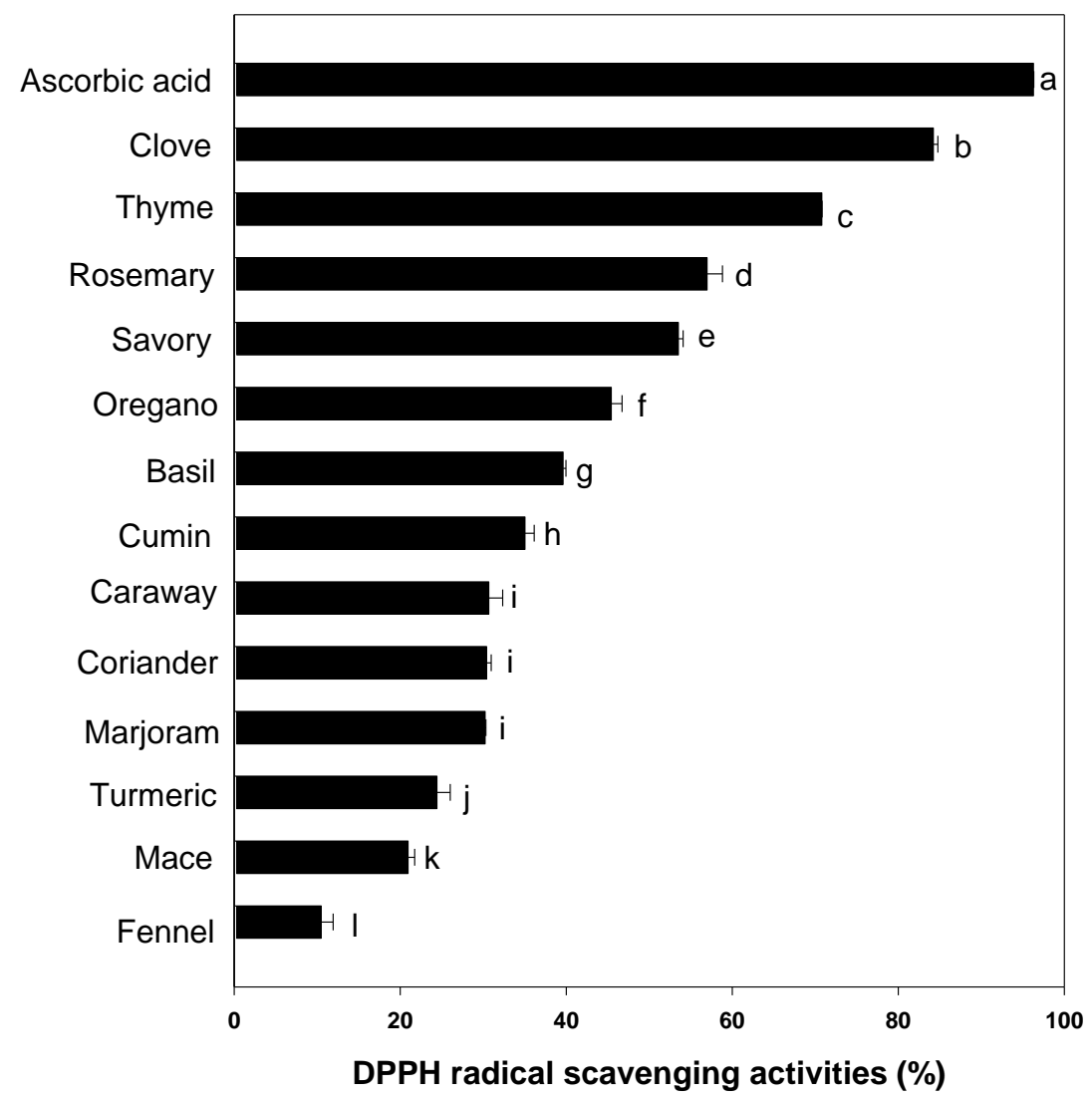

\subsection{Superoxide Anion Radical Scavenging Activity}

Superoxide anion $\left(\mathrm{O}_{2}{ }^{\bullet-}\right)$ is generated from oxygen $\left(\mathrm{O}_{2}\right)$ by multiple pathways such as oxidation by NADPH oxidase, xanthine or hypoxanthine oxidase. Generally, superoxide anion is converted to hydrogen peroxide by superoxide dismutase (SOD) or reacts with nitric oxide $\left(\mathrm{NO}^{\bullet}\right)$ to form peroxynitrite. Hydrogen peroxide can be further converted to water and oxygen by catalase and glutathione peroxidase. However, superoxide is believed to be the cause of other ROS formations such as hydrogen peroxide, peroxynitrite, and hydroxyl radicals. Superoxide anion is a reduced form of molecular oxygen created by receiving one electron. Superoxide radicals have been observed to kill cells, inactivate enzymes, and degrade DNA, cell membranes and polysaccharides [3,7]. It was, therefore, proposed to measure the comparative interceptive ability of antioxidant extracts to scavenge the superoxide radical [21]. The superoxide radical scavenging effect of the different spices of water extract was compared at the same dose as ascorbic acid $(0.5 \mathrm{mg} / \mathrm{mL})$ as shown in Figure 2. When compared to ascorbic acid (36.48\%), the superoxide anion radical scavenging activities of marjoram, rosemary, oregano, savory, cumin, basil, thyme, fennel and coriander were higher than that of ascorbic acid. In contrast, the activities of mace, turmeric, clove and caraway were lower than that of ascorbic acid ( $\mathrm{p}<0.001)$. We found that marjoram extract had stronger superoxide anion scavenging activity than other spices extract. These results suggest that phenolic compounds in marjoram possess strong antioxidant effects due to superoxide anion radical scavenging in the cellular level. 
Figure 2. Superoxide radical scavenging activity of hot water extracts of spices at the concentration of $0.5 \mathrm{mg} / \mathrm{mL}$ ( $\mathrm{n}=6$, error bars represent standard deviation). ${ }^{\mathrm{a}-\mathrm{m}}$ Values are significantly different between the samples $(\mathrm{p}<0.001)$.

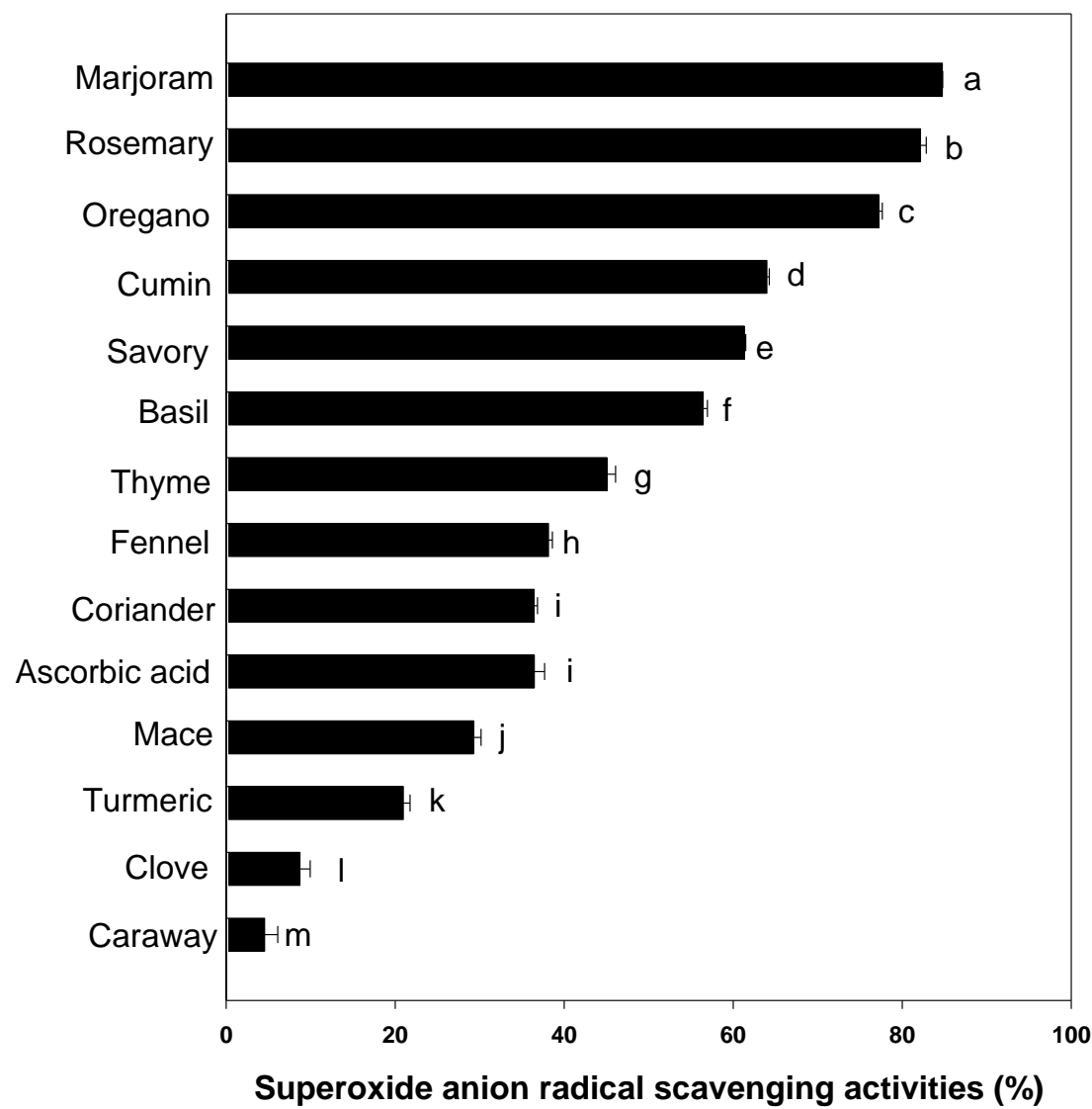

\subsection{Hydroxyl Radical Scavenging Activity}

Among the reactive oxygen species (ROS), hydroxyl radicals are the most reactive and predominant radicals generated endogenously during aerobic metabolism to initiate cell damage in vivo [14,22]. We examined the inhibitory action of the samples on deoxyribose degradation which gives an indication of hydroxyl radical scavenging action [23,24]. Hydroxyl radical scavenging activities of selected spices at a concentration of $0.5 \mathrm{mg} / \mathrm{mL}$ in relation to ascorbic acid at the same concentration are shown in Figure 3.

The result in decreasing order of hydroxyl radical scavenging activity was turmeric (68.09\%) > mace $(60.34 \%)>$ ascorbic acid $(48.72 \%)>$ oregano $(45.75 \%)$, fennel $(44.63 \%)>$ rosemary $(29.29 \%)>$ basil $(25.25 \%)>$ coriander $(21.94 \%)$, savory $(20.43 \%)$, thyme $(19.64 \%)>$ clove $(10.78 \%)$, caraway $(9.72 \%)$, marjoram $(7.84 \%)>$ cumin $(2.95 \%)$ ( $\mathrm{p}<0.001)$. Hydroxyl radical scavenging activity of the turmeric extract was higher than other spices extract (Figure 3). However, hydroxyl radical scavenging activity of turmeric extract showed a different pattern with different methods used such as DPPH and superoxide anion scavenging abilities. Interestingly, the antioxidant activity varies depending on methods used [25,26]. Bioactive compounds in various spices are a complex mixture of compounds. The concentration of the phenolic and flavonoid compounds in various spices varies depending on the cultivar and climate. In addition, Yoo et al. [26] reported there are many methods for determination of 
antioxidant capacity and each method has its own limitation. It was shown that some antioxidant assays give different antioxidant activity trends. Taken together, our results show that the antioxidant activities of various spices have different tendencies, which may depend on the methods used and/or the profile of phenolics.

Figure 3. Hydroxyl radical scavenging activities of spices in the concentration of $0.5 \mathrm{mg} / \mathrm{mL}$. ( $\mathrm{n}=6$, error bars represent standard deviation). ${ }^{\mathrm{a}-1}$ Values are significantly different between the samples $(\mathrm{p}<0.001)$.

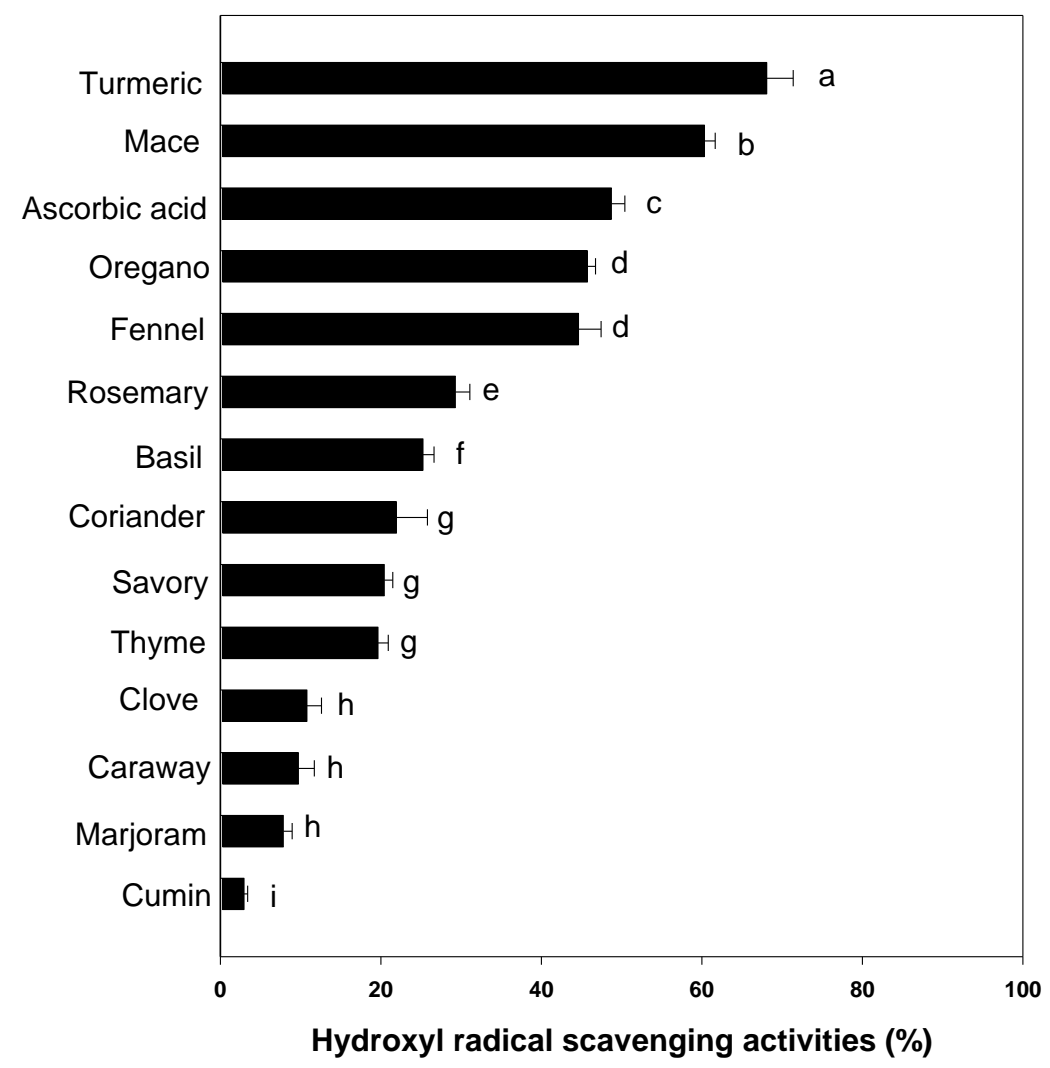

\subsection{Correlation Among the Antioxidant Characteristics}

Total phenolic and flavonoid contents have been reported to be responsible for the antioxidant activities of botanical extracts. DPPH, hydroxyl radical scavenging activity, and superoxide anion radical scavenging activity have been used to measure antioxidant activity and these results should correlate with those of total phenolic and flavonoids content. A recent report $[19,27]$ demonstrated that some bioactive compounds present in medicinal plants possessed high total antioxidant activity, which was due to the presence of phenolic, carotenoids and flavonoids. A regression analysis was used to correlate the results of the five assays (Table 2). 
Table 2. Correlations $\left(\mathrm{r}^{\mathrm{a}}\right)$ between different antioxidant capacity parameters (by DPPH, hydroxyl, and superoxide radical scavenging activity) and total phenolic contents or flavonoid contents of various spices' water extracts.

\begin{tabular}{|c|c|c|c|c|c|}
\hline & TPC $^{b}$ & Flavonoid & DPPH $^{c}$ & HRSA $^{d}$ & SRSA $^{\mathrm{e}}$ \\
\hline TPC & & 0.3164 & $0.9158 * * *$ & -0.1422 & -0.1052 \\
\hline Flavonoid & & & $0.5430 *$ & -0.2599 & $0.5598 *$ \\
\hline DPPH & & & & -0.4218 & 0.0434 \\
\hline HRSA & & & & & -0.1422 \\
\hline
\end{tabular}

${ }^{\mathrm{a}} \mathrm{r}$, correlation coefficient; ${ }^{\mathrm{b}} \mathrm{TPC}$, total phenolic content; ${ }^{\mathrm{c}}$ DPPH radical scavenging activity;

${ }^{\mathrm{d}}$ HRSA, hydroxyl radical scavenging activity; ${ }^{\mathrm{e}} \mathrm{SRSA}$, superoxide anion radical scavenging activity. Significance level at $* * p<0.01$ and $* * * p<0.001$.

High correlation coefficients were found between the total phenolic content and DPPH radical scavenging activity $(\mathrm{r}=0.9158, \mathrm{p}<0.001)$. The flavonoid content exhibited moderate correlation coefficients and DPPH radical scavenging activity and superoxide anion radical scavenging activity (respectively, $r=0.5430, r=0.5598, p<0.05$ ). However, a non-significant correlation coefficient was found between flavonoid content and total phenolic content $(\mathrm{p}>0.05)$. In addition, no significant correlation coefficient between flavonoid and hydroxyl and superoxide anion radical scavenging activity was found $(\mathrm{p}>0.05)$. As the aluminum chloride method is specific only for flavones and flavonols, total flavonoid content could be underestimated by the method [28], which probably accounts for a lower correlation observed between antioxidant activity and flavonoid count. Liu et al. [20] reported a negative correlation between flavonoid content and antioxidant activity.

\section{Experimental Section}

\subsection{Chemicals and Spices}

Ascorbic acid, potassium persulphate, disodium hydrogen phosphate $\left(\mathrm{Na}_{2} \mathrm{HPO}_{4}\right)$ 2,2-diphenyl-1-picrylhydrazyl (DPPH), deoxyribose, ferric chloride ( $\left.\mathrm{FeCl}_{3}\right), \mathrm{MEDTA}$, hypoxantine, nitroblue tetrazolium (NBT), xanthine oxidase, Folin-Ciocalteu's phenol reagent, (+)-catechin, quercetin, sodium nitrite $\left(\mathrm{NaNO}_{2}\right)$, aluminum chloride $\left(\mathrm{AlCl}_{3}\right)$, linoleic acid, thiobarbituric acid (TBA) and trichloroacetic acid (TCA) were purchased from Sigma Co. (St. Louis, MO, USA). Sodium hydroxide $(\mathrm{NaOH})$, hydrogen peroxide $\left(\mathrm{H}_{2} \mathrm{O}_{2}\right)$ and all solvents used were of analytical grade were purchased from Merck Co. (Darmstadt, Germany). Distilled deionized water (dd. $\left.\mathrm{H}_{2} \mathrm{O}\right)$ was prepared by Ultrapure TM water purification system (Lotun Co., Ltd., Taipei, Taiwan). The selected spices and herbs were purchased from Taewon Food Industry (Seoul, Korea) in Korea (Table 1).

\subsection{Extraction Yield of Samples}

Spices samples were dried for $48 \mathrm{~h}$ to about $4 \%$ moisture (dry base) in a hot air-drier at $50{ }^{\circ} \mathrm{C}$. After drying, $4 \mathrm{~g}$ of dried sample were extracted with $40 \mathrm{~mL}$ of distilled water at a temperature from 80 to $100{ }^{\circ} \mathrm{C}$ in reflux for $3 \mathrm{~h}$ to give an initial extract (fraction I). The residues were extracted with $60 \mathrm{~mL}$ of distilled water at a temperature from 80 to $100{ }^{\circ} \mathrm{C}$ for $0.5 \mathrm{~h}$ to give fraction II. After cooling to room temperature and then filtering (Whatman No 2), the two fractions were combined and dried under 
vacuum below $40{ }^{\circ} \mathrm{C}$ and weighed to determine the yield. The extracts were completely dried in a freeze-drier and stored at $-20{ }^{\circ} \mathrm{C}$ until further use.

\subsection{Measurement of Free Radical Scavenging Activity on DPPH Assay}

The free radical scavenging activity of samples $(1 \mathrm{mg} / \mathrm{mL}$ in DMSO) was measured using the method of Brand-Williams et al. [29] with some modification. L-ascorbic acid was used as a positive control. The inhibition percentage was calculated from the following equation: Inhibition $\%=[($ absorbance of control - absorbance of sample $) /$ absorbance of control $] \times 100$. The absorbance was measured by a spectrophotometer (Ultrospec 2100 pro; Amersham Pharmacia Biotech Co., Piscataway, NJ, USA).

\subsection{Measurement of Superoxide Anion $\left(\mathrm{O}_{2}{ }^{\bullet-}\right)$ Radical Scavenging Activity}

Superoxide radicals were generated by a modified method of Liu et al. [30]. The samples $(0.5 \mathrm{mg} / \mathrm{mL}$ in DMSO) were added to the reaction solution containing $100 \mu \mathrm{L}$ of $30 \mathrm{mM}$ EDTA (pH 7.4), $10 \mu \mathrm{L}$ of $30 \mathrm{mM}$ hypoxantine in $50 \mathrm{mM} \mathrm{NaOH}$, and $200 \mu \mathrm{L}$ of $1.42 \mathrm{mM}$ nitroblue tetrazolium (NBT). After the solution was preincubated at room temperature for $3 \mathrm{~min}, 100 \mu \mathrm{L}$ of $0.5 \mathrm{U} / \mathrm{mL}$ xanthine oxidase was added to the mixture and the volume was brought up to $3 \mathrm{ml}$ with $50 \mathrm{mM}$ phosphate buffer ( $\mathrm{pH}$ 7.4). After the solution was incubated at room temperature for $20 \mathrm{~min}$, absorbance was measured at $560 \mathrm{~nm}$. The reaction mixture without xanthine oxidase was used as a blank (A1). The samples (A2) were added to the reaction mixture, in which $\mathrm{O}_{2}{ }^{\bullet-}$ was scavenged, thereby inhibiting the NBT reduction. Absorbance was measured and the decrease in $\mathrm{O}_{2}{ }^{\bullet-}$ was represented by A2-A1. The scavenging activity on superoxide anion radical (SRSA) was calculated by the following equation: SRSA $\%=(\mathrm{A} 2-\mathrm{A} 1 / \mathrm{A} 1) \times 100$.

\subsection{Measurement of Hydroxyl $\left(\mathrm{OH}^{\bullet}\right)$ Radical Scavenging Activity}

The scavenging activity of samples in DMSO on the hydroxyl radical $\left(\mathrm{OH}^{\bullet}\right)$ was measured by the deoxyribose method [23] with a slight modification. The deoxyribose assay was performed in $10 \mathrm{mM}$ phosphate buffer ( $\mathrm{pH}$ 7.4) containing $2.5 \mathrm{mM}$ deoxyribose, $1.5 \mathrm{mM} \mathrm{H}_{2} \mathrm{O}_{2}, 100 \mu \mathrm{M} \mathrm{FeCl}_{3}, 104 \mu \mathrm{M}$ EDTA, and the test sample $(0.5 \mathrm{mg} / \mathrm{mL})$. The reaction was started by adding ascorbic acid to a final concentration of $100 \mu \mathrm{M}$. The reaction mixture was incubated for $1 \mathrm{~h}$ at $37{ }^{\circ} \mathrm{C}$ in a water-bath. After incubation, the color was developed by addition of $0.5 \%$ thiobarbituric acid followed by ice-cold $2.8 \%$ trichloroacetic acid in $25 \mathrm{mM} \mathrm{NaOH}$ and heating for $30 \mathrm{~min}$ at $80{ }^{\circ} \mathrm{C}$. A control was performed without samples (A1). The sample (A2) was cooled on ice and the absorbance was measured at $532 \mathrm{~nm}$. The hydroxyl radical scavenging activity (HRSA) was calculated by the following equation: $\mathrm{HRSA} \%=(\mathrm{A} 1-\mathrm{A} 2 / \mathrm{A} 1) \times 100$.

\subsection{Measurement of Total Phenolic Content Using Folin-Ciocalteu Assay}

Total phenolic contents of the extracts were determined spectrophotometrically according to the Folin-Ciocalteu colorimetric method [31]. Because catechin is one of the polyphenol compounds, total 
phenolic content of hot water extract form 13 spices were expressed as microgram catechin equivalents (CE)/gram.

\subsection{Measurement of Total Flavonoids}

Total flavonoid was determined using the method of Meda et al. [28] with minor modifications. In brief, $0.25 \mathrm{~mL}$ of sample $(1 \mathrm{mg} / \mathrm{mL})$ was added to a tube containing $1 \mathrm{~mL}$ of double-distilled water. Next, $0.075 \mathrm{~mL}$ of $5 \% \mathrm{NaNO}_{2}, 0.075 \mathrm{~mL}$ of $10 \% \mathrm{AlCl}_{3}$ and $0.5 \mathrm{~mL}$ of $1 \mathrm{M} \mathrm{NaOH}$ were added at 0,5 and $6 \mathrm{~min}$, sequentially. Finally, the volume of the reacting solution was adjusted to $2.5 \mathrm{~mL}$ with double-distilled water. The absorbance of the solution at a wavelength of $410 \mathrm{~nm}$ was detected using the Ultrospec 2100 pro spectrophotometers (Section 3.3). Quercetin is a ubiquitous flavonoid, present in many plant extract, was used as standard to quantify the total flavonoid content of hot water extract of the spice extracts. Results were expressed in microgram quercetin equivalents (QE)/gram.

\subsection{Statistical Analysis}

The results were reported as mean \pm standard deviation (SD). The significance of differences among treatment means was determined by analysis of variance (one-way ANOVA) using SAS version 8.1 (SAS Institute, Cary, NC, USA). Correlation analyses were performed using the Pearson's correlation coefficient (r).

\section{Conclusions}

In these results we have focused on hot water extracts obtained from 13 spices commonly used in meat products for their antioxidant properties, which have rarely been reviewed. Results of these antioxidant activities of selected spices using three different assays, such as DPPH assay, superoxide radical scavenging activity, and hydroxyl radical scavenging activity were presented. This analysis technique could provide insight into the variations in the antioxidant profiles between different spices and could help disease prevention and cure using simple herbs and spices. Several spices were found to have high levels of antioxidant capacity and total phenolic compounds. Moreover, the antioxidant capacity, total phenolic content and flavonoid contents of the 13 selected spices were different from each other. Among the selected spices, the clove, thyme and rosemary extracts exhibited higher DPPH radical scavenging activities. In addition, the marjoram, rosemary and oregano extracts exhibited higher superoxide anion radical scavenging activities, and turmeric and mace exhibited higher hydroxyl radical scavenging activities. Interestingly, clove and turmeric showed highest total phenolic content and flavonoid content, respectively, associated with the relatively higher antioxidant activities among these spices. These results suggest that several spices extracts have potential as possible functional ingredients in meat products.

\section{Acknowledgments}

This work was supported by Priority Research Centers Program through the National Research Foundation of Korea (NRF) funded by the Ministry of Education, Science and Technology (2009-0093813). 


\section{References}

1. Frankel, E.N.; Meyer, A.S. The problems of using one-dimensional methods to evaluate multifunctional food and biological antioxidants. J. Sci. Food Agric. 2000, 80, 1925-1941.

2. Carpenter, R.; O’Grady, M.N.; O'Callaghan, Y.C.; O’Brien, N.M.; Kerry, J.P. Evaluation of the antioxidant potential of grape seed and bearberry extracts in raw and cooked pork. Meat Sci. 2007, 76, 604-610.

3. Halliwell, B. Ascorbic acid in the prevention and treatment of cancer. Altern. Med. Rev. 1996, 3, 174-186.

4. Madhavi, D.L.; Deshpande, S.S.; Salunkhe, D.K. Food Antioxidants: Technological, Toxicological, Health Perspective; Marcel Dekker: New York, NY, USA, 1996; pp. 1-5.

5. Tachakittirungrod, S.; Okonogi, S.; Chowwanapoonpohn, S. Study on antioxidant activity of certain plants in Thailand: Mechanism of antioxidant action of guava leaf extract. Food Chem. 2007, 103, 381-388.

6. Amro, B.; Aburjai, T.; Al-Khalil, S. Antioxidative and radical scavenging effects of olive cake extract. Fitoterapia 2002, 73, 456-461.

7. Cai, Y.Z.; Luo, Q.; Sun, M.; Corke, H. Antioxidant activity and phenolic compounds of 112 Chinese medicinal plants associated with anticancer. Life Sci. 2004, 74, 2157-2184.

8. Moure, A.; Cruz, J.M.; Franco, D.; Dominguez, J.M.; Sineiro, J.; Dominguez, H.; Nunez, M.J.; Parajo, J.C. Natural antioxidants from residual sources. Food Chem. 2001, 72, 145-171.

9. Ringman, J.M.; Frautschy, S.A.; Cole, G.M.; Masterman, D.L.; Cummings, J.L. Potential role of the curry spice curcumin in Alzheimer's disease. Curr. Alzheimer Res. 2005, 2, 131-136.

10. Ahmed, R.S.; Seth, V.; Banerjee, B.D. Influence of dietary ginger (Ziniber officinales Rosc) on oxidative stress induced by malathion in rats. Food Chem. Toxicol. 2000, 38, 443-450.

11. Modak, M.; Dixit, P.; Londhe, J.; Ghaskadbi, S.; Paul, A.; Devasagayam, T. Indian herbs and herbal drugs used for the treatment of diabetes. J. Clin. Biochem. Nutr. 2007, 40, 163-173.

12. Kikuzaki, H.; Nakatani, N. Antioxidant effects of some ginger constituents. J. Food Sci. 1993, 55, 2237-2340.

13. Manda, K.R.; Adams, C.; Ercal N. Biologically important thiols in aqueous extracts of spices and evaluation of their in vitro and antioxidant properties. Food Chem. 2010, 118, 589-593.

14. Park, E.J.; Pezzutto, J.M. Botanicals in cancer chemoprevention. Cancer Metastasis Rev. 2002, 21, 231-255.

15. Hinneburg, I.; Damien, H.J.; Hiltunen, R. Antioxidant activities of extracts from selected culinary herbs and spices. Food Chem. 2006, 97, 122-129.

16. Foti, M.; Piattelli, M.; Baratta, M.T.; Ruberto, G. Flavonoids, coumarins, and cinnamic acids as antioxidants in a micellar system structure-activity relationship. J. Agric. Food Chem. 1996, 44, 497-501.

17. Miliauskas, G.; Venskutonis, P.R.; van Beek, T.A. Screening of radical scavenging activity of some medical and aromatic plant extracts. Food Chem. 2004, 85, 231-237.

18. Rice-Evans, C.A.; Miller, N.J.; Paganga, G. Structure-antioxidant activity relationships of flavonoids and phenolic acids. Free Radic. Biol. Med. 1996, 20, 933-956. 
19. Zheng, W.; Wang, S. Antioxidant activity and phenolic compounds in selected herbs. J. Agric. Food Chem. 2001, 49, 5165-5170.

20. Liu, H.; Qiu, N.; Ding, H.; Yoa, R. Polyphenols contents and antioxidant capacity of 68 Chinese herbs suitable for medical or food uses. Food Res. Int. 2008, 41, 363-370.

21. Vani, T.; Rajani, M.; Sarkar, S.; Shishoo, C.J. Antioxidant properties of the ayurvedic formulation triphala and its constituents. Int. J. Pharmacog. 1997, 35, 313-317.

22. Mates, J.M.; Sanchez-Jimenez, F.M. Role of reactive oxygen species in apoptosis: Implications for cancer therapy. Int. J. Biochem. Cell Biol. 2000, 32, 157-170.

23. Lopes, G.K.; Schulman, H.M.; Hermes-Lima, M. Polyphenol tannic acid inhibits hydroxyl radical formation from Fenton reaction by complexing ferrous ions. Biochim. Biophy. Acta 1999, 1472, $142-152$.

24. Halliwell, B.; Gutteridge, J.M.C.; Aruoma, O.I. The deoxyribose method: A simple "test-tube" assay for determination of rate constants for reactions of hydroxyl radicals. Anal. Biochem. 1987, $165,215-219$.

25. Lee, O.H.; Lee, B.Y.; Kim, Y.C.; Shetty, K.; Kim, Y.C. Radical scavenging-linked antioxidant activity of ethanolic extracts of diverse types of extra virgin olive oils. J. Food Sci. 2008, 73, C519-C525.

26. Yoo, K.M.; Kim, D.O.; Lee, C.Y. Evaluation of different methods of antioxidant measurement. Food Sci. Biotechnol. 2007, 16, 177-182.

27. Do, J.R.; Kang, S.N.; Kim, K.J.; Jo, J.H.; Lee, S.W. Antimicrobial and antioxidant activities and phenolic contents in the water extract of medicinal plants. Food Sci. Biotechnol. 2004, 13, 640-645.

28. Meda, A.; Lamien, C.E.; Romito, M.; Millogo, J.; Nacoulma, O.G. Determination of the total phenolic, flavonoid and proline contents in Burkina Fasan honey, as well as their radical scavenging activity. Food Chem. 2005, 91, 571-577.

29. Brand-Williams, W.; Cuvelier, M.E.; Berset C. Use of a free radical method to evaluate antioxidant activity. LWT-Food Sci. Technol. 1995, 28, 25-30.

30. Liu, F.; Ooi, V.E.C.; Chang, S.T. Free radical scavenging activity of mushroom polysaccharide extracts. Life Sci. 1997, 60, 763-771.

31. Singleton, V.L.; Rossi, J.R. Colorimetry of total phenolics with phosphomolybdic-phosphotungstic acid. Am. J. Enol. Vitic. 1965, 16, 144-158.

(C) 2011 by the authors; licensee MDPI, Basel, Switzerland. This article is an open access article distributed under the terms and conditions of the Creative Commons Attribution license (http://creativecommons.org/licenses/by/3.0/). 